日本機械学会論文集 (A 編)

76 巻 767 号 $(2010-7)$

\title{
「ガスタービン用遮熱/耐環境コーティング技術」 小特集号発刊にあたって*
}

\author{
山崎泰広*1 \\ On the Occasion of a Special Issue on \\ “Thermal Barrier Coating Systems for Gas Turbines"
}

\author{
Yasuhiro YAMAZAKI*2 \\ *2 Department of Mechanical and Control Engineering, Niigata Institute of Technology, \\ 1719 Fujihashi, Kashiwazaki-shi, Niigata, 945-1195 Japan
}

エネルギー産業分野に扔いても環境負荷低減, $\mathrm{CO}_{2}$ 削減が喫緊の重要課題となって晾り，起動性能や熱効 率に優れた産業用ガスタービンへの要求と期待はさら に高まっている.タービン動・静翼などガスタービン で使われる高温機械部品・部材の強度的信頼性を高 め, 寿命を延伸する工学技術は, 新規ガスタービンを 開発するための根幹を担っている。また,これら部品, 部材の機能を向上させる遮熱/耐環境コーティングに 関する研究は，最近のキーテクノロジーとなってい る。これら課題注機械工学, 材料工学, 環境工学, 物 理, 化学等の分野にまたがり, かつ, 産学官にまたが る三位一体の横断的な取り組みが不可欠な分野横断的 領域位位置している。

このような背景の下, 日本学術振興会の援助を得て, 2009 年 5 月に「第 2 回ガスタービン遮熱コーティン グに関する日独ワークショップ」が開催された。そこ
では,「地球と科学技術との共存」をキャッチフレー ズに, ガスタービン用遮熱/耐環境コーティングに関 連した基礎技術と工学, コーティングの組織制御と機 械的/物理的/化学的特性, 将来的に見込末れる国際標 準規格 ISO などの制定動向やそれにむけた基礎工学 情報などに関する情報交換が行われた，本小特集号 は，そこで発表された研究論文，および，一般から投 稿いただいた研究論文をあわせ，厳正な審查を経て小 特集号として発刊するものである。本小特集が本学会 会員および関連工学分野の研究者および技術者の方及 の今後の学術的/工学的向上に役立てば至福である. な抢このテーマに関する類似の特集号が本学会の英 文ジャーナル Journal of Solid Mechanics and Materials Engineering(Vol. 4, No. 2) においても企画され, 発刊されている。これもあわせて参照いただければ幸 甚である。

* 原稿受付 2010 年 6 月 14 日

*1 正員, 新潟工科大学工学部 (-945-1195 柏崎市藤橋 1719).

E-mail : axel@mce.niit.ac.jp 